\title{
Critical evaluation of the doctrine of predestination within black-African theology: Christ the elected and electing
}

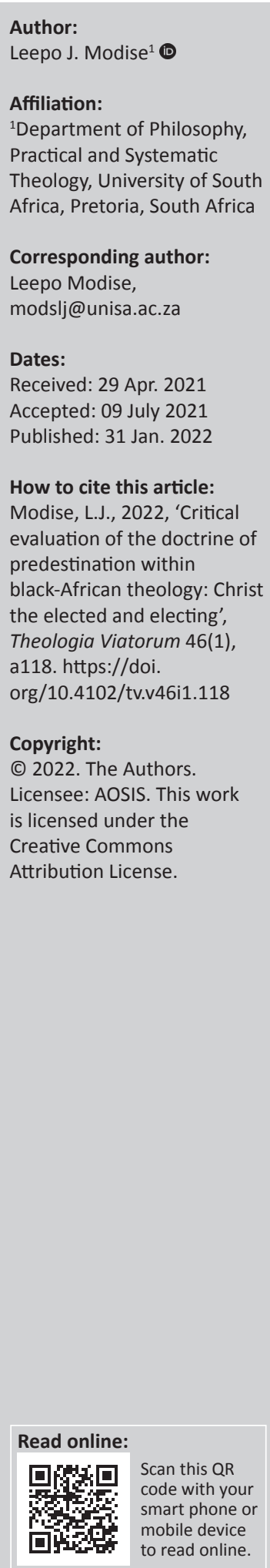

\begin{abstract}
This article aims to deconstruct the ideology about God's election in South Africa, which is attached to capitalism. I will discuss its impact on the South African socio-politico-economic situation in the apartheid and post-apartheid era. Furthermore, I will critically discuss the equality of human beings in the eyes of Triune God and focus on the centrality of Christology from the African and black theology. One cannot divorce the Providence of God from the doctrine of predestination. The God who creates is the same God who elects and provides for his people. This argument will lead to the critical question: Who are the elect, rich or poor? Free or oppressed? This article's final thesis is to deconstruct the ideology that God elects according to God's grace.
\end{abstract}

Keywords: critical; predestination; black; African; Christ; elected and electing.

\section{Introduction}

When one reflects on the theological justification of separation and capitalism in South Africa, John Calvin and Reformed theology are frequently echoed to justify dualism or paradox of the rich and the poor, oppressed and the free human beings (Resane 2017:116). The doctrine of predestination is central to this dualism. I would like to declare that I am a black African and Reformed theologian. Black African in terms of birth as Mosotho (Mofokeng wa Matshele) traced back to Leribe in Lesotho where my paternal genealogy originated, a product of Mofokeng and Mokwena wa Sechele (Maternal origin) - reformed in terms of baptismal, Christian upbringing, education and vocation. My Africanism needs to influence my Reformed theology.

My engagement in theology during my university studies, ministry in Uniting Reformed Church and a lectureship in the University of South Africa has created curiosity on the doctrine of predestination within black and African theology. From reading the Bible and Belhar confession, ${ }^{1}$ this doctrine could not make sense to me when related to capitalists and the affluent. In this article I will wrestle with this doctrine by using the Political theology, black theological methodology in particular and African approach to deconstruct the constructed sense-making that God chooses individuals or specific people and left the others outside God's grace. This doctrine's origin will be traced back to John Calvin and Theodore Beza, with references to other Reformed theologians. The particular focus will be on Karl Barth Christology on this doctrine, evaluating this Christology by using James Cone's Christology on the very same doctrine. This lecture will fall within Political by theology using the descriptive-normative methodology.

\section{Problem statement}

The colonisers used the doctrine of predestination to dehumanise Africans in South Africa. The justification was based on the claim that colonisers are the elects whereas the indigenous people are not (Magubane 2007:182-183; Resane 2017:117). According to Resane (2017:116), the very same doctrine was used to instil the inferiority complex into Africans in Africa and the diaspora. In South Africa, Afrikaner religious persuasion originates from the 16th century reformed tradition's Protestant practices, pioneered by the Swiss theologian John Calvin (1509-1564). John Calvin believes that the church should influence government policy and that races should remain pure and separate. This tradition has led to changes in a unique brand of Protestantism in South Africa. Apartheid policies were supported by Afrikaner religious doctrines such as the doctrine of predestination. In their long run for survival, they slowly came to identify themselves with the

1.The Belhar Confession is the South African origin confession, which was adopted in Cape Town Belhar suburb by the then Dutch Reformed Mission Church that emphasises justice, unity and reconciliation. It is now an ecumenical confession. 
Nation of Israel as the elect of God (Resane 2017:116-117). The identification with Israel or Jews as the Nation is also questionable during the Jewish persecution in Germany throughout the Nazi period. Vasilopoulos (2012) postulated:

Many Jews accepted this formulation for those with more conservative or traditional views, identity was a communal or national property. Not a person who happened to have Jewish antecedents, a Jew was a creature of the Covenant, one of God's Chosen People, a member of Nation created and chosen by God for a special mission. The racist implications of divine election have been often cited by Jews, as well as their critics: The notion of race as such, defined as a set of common physical and mental characteristics transmitted within a group by force of tradition or even in some biological way, had been used by Jews themselves from Moses to Martin Buber ... No notion of natural rights nor anything else, could change a Jew's identity. By virtue of this conviction, it was virtually impossible to avoid the implication that the Jews were a nation within a nation. Moreover, for nonJews, especially conservative or traditional Catholics, Jews were considered different because they had been designed by God, not as the Chosen, but as the rejected. (p. 248)

The identification of the Europeans in South Africa with the Jews or Israel as a nation was as equal as creating a European society within an entire African community without borders. The identification as different people does not guarantee God's election, but designed differently. Hence, they fall outside the Providence of God. The Jewish people were using Political theology to access the Nation's wealth, which they enforced themselves into that Nation as a nation within the Nation. The same as the Dutch use this doctrine to force themselves as a nation within the other Nation.

Together with the doctrine of Providence, the doctrine of predestination was abused to gain access to the African wealth and land in South Africa. Magubane (2007:181) argues that Europeans may kill the indigenous people for their heads of cattle because of Providence claimed to be given to the elects (Europeans). According to Magubane (2007:181), van Riebeeck characteristically blending piracy and piety wondered at the ways of Providence, which permitted such noble animals to remain in possession of the so-called heathens. Similarly, the indigenous people's human dignity and rights have led Europeans, in particular the Dutch people, to take the land of the indigenous people (Magubane 2007:181-182). Land dispossession is one of the challenges of interpretation of this doctrine: the elects, those whom God has provided with wealth or those who have killed others for their wealth. There is no way that the doctrine of election can be divorced from the doctrine of Providence, hence the question of who are the elects based on the way van Riebeeck, on the argument of dispossession. Dolamo (2016:47) lays the foundation on the role of this doctrine in terms of coloniality. He argues that the colonialists and missionaries, when they invaded South Africa mainly, Africa in general and lands elsewhere belonging to the indigenous peoples were to empty them of their identity. Colonialists perceive the people of the land as savages and uncivilised. Missionaries branded them as heathens or pagans, in the context of this article, rejected by God or people who have fallen out of the grace of
God. The victims of the conquest would be remoulded and given identities, contemporary culture and a new religion that was Christianity, which was prescribed as a new way of life. Those who resisted being remoulded were murdered. Genocide was committed in South Africa, Africa, Asia and America. It was easy to murder a black person because he or she is not elected by God (Dolamo 2016:47). Hence, this article aims to reconstruct black people's identity as part of God's elect or elected people.

Thielicke (1969:573) postulates that the pre-temporal character of predestination and all other loci follow systematically upon that doctrine, including even the article on Providence. Creation is treated between predestination and Providence's doctrines, thus underscoring the leading role of the decree of election. The question to be answered in this article is, 'who are the elects [in terms of or in the light of] the African-black theological interpretation of predestination?' Thielicke (1969:573) raises the question of what is the yardstick to measure that an individual is confident of his or her election. The response to that question was such assurance is possible only when a person realises God's blessing on his life. I will engage this question and answer further in this article. There has been a description of this doctrine to the function of politics in South Africa. The methodology that will be followed in this article is descriptive-normative in Political theology to engage the question 'who are the elect?' which is rarely answered within the theological debate on Predestination by many theologians. The interpretation of this doctrine has a negative impact and contribution to racism and economic injustice. Answering the question of who are the elects is based on the engagement of predestination and Providence of God.

\section{Theological approach and methodology employed}

This article's theological framework is Christology, where Christ is the centre of the argument; as stated in the abstract, Political theology will be used to select the methodology to follow. Hunsinger (2012:271) indicates that political theology belongs to two categories, the descriptive and normative, and they are normally intertwined. Descriptive accounts might have normative agenda, whilst normative accounts usually include political descriptions - descriptive accounts, at how it ought to operate (Hunsinger 2012:271). Descriptive accounts examine how theology influence the political context, whilst normative accounts examine how political context ought to function. This theological doctrine influenced the political context, and the same doctrine ought to respond to the results of this doctrine's results in South Africa.

In this article, I will employ a descriptive-normative method to address the problem at hand. Furthermore, I will look into how theology functions in the political sphere and how theology ought to function. Metz (2012:273) argues that Political theology needs to explore how the ways of sufferings of the people, such as poverty, ill-health and exploitation, can 
be and how frequent they are, obscured and exacerbated by religion. It also needs to develop theological remedies that, however, will require not only more careful social and cultural analyses but also more perspective retrievals from the theological tradition (Metz 2012).

Political theology as the method to examine the sufferings of the people in general and Africans in particular in the context of this article is the basis where the researcher builds up the argument to make sense of the doctrine of predestination within the African and Black theological understanding of the doctrine based on Christ. The researcher will use Political theology to detect the suffering of the Africans based on this doctrine and construct the ways of addressing the causes of this suffering through deconstructing the interpretation of this doctrine.

Christology is used to deconstruct the constructed mentality that the doctrine of Predestination in South Africa advances certain group of people. Christ-centred interpretation of the political reality will be the central point of departure to make sense of this doctrine. In the reproduced work of Bonhoeffer on church and state, Bonhoeffer (2012:289) argued in favour of the advantages of interpreting political reality from a centre 'in Christ' as opposed to one 'in human nature' or 'in $\sin ^{\prime}$. Suppose that Jesus Christ is the origin and goal of all things - the medium through whom God governs. In that case, he is the origin, purpose and medium of divine governance in the political realm - whether through the church or apart from the church or even against the church (Bonhoeffer 2012:289).

\section{Towards the role of Christ in predestination in black-African theology}

The doctrine of predestination is a John Calvin formulation based on reading and engaging with the biblical texts relating to the people's election according to the will and free grace of God. Predestination is one of the doctrines that have so many controversies since the 16 th century to date. Many theologians and scholars could not understand how can God elect others and pass others (Calvin 2009:615). Barth and Bonhoeffer have indicated that Christ is the originator and goal of theology. In this section, Barthian theology on predestination will be a point of departure that will flow towards the development of black theology of James Cone and the African theology on Christ as ancestor and member of the community of the living and the dead.

The knowledge of God is possible through God-self. Thus, the understanding of predestination is through God in Christ. Barth (1957:3) indicates that the doctrine of election summarises the good news because all words that are said or heard are the best; God elects human beings; that God is for the human being too, the One who loves freedom. This knowledge and free love are grounded in Jesus Christ's experience because Jesus Christ is both the electing human being and elected human being in One. It is part of the predestination not merely of human beings but God-self (Barth 1957:3).

Barth (1957:7-9) postulates that the predestination manifests itself in the incarnation, the movement of Jesus to become human and identify himself with humanity. In this sense, Barth emphasises the fact that Jesus is the elect of God, and at the very same time, he is electing those who are predetermined by the community of God - the Triune God pretemporal. Jesus, who is the Son and a member of God's community, is called Jesus of Nazareth. He is part of the community. He is the community representative, which in Jesus-self and through Jesus is united as he is God, being with Jesus, the object of the divine movement (Barth 1957:7). This argument on Jesus, the community's representative, leads us to the analysis of Jesus the elected and electing the divine. Historical Jesus is the central point of discussion. Barth (1957) indicates:

In His movement towards man, Jesus Christ is indeed God or, more exactly, in His movement towards the people represented in the one man Jesus of Nazareth, in His Covenant with this people, in His being and activity amongst and towards this people. Jesus Christ is the decision of God in favour of this attitude or relation. He is Himself the relation. It is a relation ad extra, undoubtedly, for both the man and the people represented in Him are creatures and not God. (p. 7)

Barth's argument is more on African epistemology, where the community of people is significant. The activity of Christ is the point of departure. The incarnation is the decision of God on the election, and the election supports the activity of Christ's ministerial vision in the Gospel of John 10:10 'I have come so that they may have life and life in abundance'. The incarnation of Christ, combined with the decision of God's community on the election, is that Jesus is the elected and electing person. The election is the divine, the choice which God makes in God's grace, thus making this movement and instituting, maintaining and directing this covenant. According to the Reformed churches' theological tradition, what they have in mind is the election of grace (Barth 1957:9). There is an emphasis on the election of Jesus in Barthian theology; God elects the man of Nazareth, despite the fact that this town was small and insignificant in the eyes of Jews, this man should be essentially one with God in God's son. Through Jesus of Nazareth and in Jesus of Nazareth, God elects God's people, thus electing the whole basis and meaning of all activities (Barth 1957:11). Jesus of Nazareth is central to the election; his ministerial vision supports Black and African theology in his mission statement in Luke 4:18-19. The ministerial mission statements of Jesus in Luke 4:18-19 are as follows:

The Spirit of the Lord is upon me because he has anointed me to preach good news to the poor. He has sent me to proclaim release to the captives and recovering of the sight to the blind, to set at liberty those who are oppressed, to proclaim the acceptable year of the Lord.

These statements assist in constructing a new dimension on predestination in the light of black theology of liberation. 
Jesus is the centre of liberation of the oppressed, and at the same time, he is on the side of the poor, oppressed, downtrodden and destitute and wronged (Belhar Confession 1986). The very same Jesus of Nazareth, who is the liberator, who takes the side of the poor and oppressed, is elected and electing (Barth 1957). In the whole argument, it is essential to locate this Jesus within the doctrine of predestination from the black theology perspective. Hence, Cone (1997, 2010) assisted contemporary theologians in contextualised Christology with other theological loci such as the doctrine of God on predestination.

Cone (2010:67) indicates that black theology cannot accommodate a colourless God in a society where human beings suffer precisely because of their colour. Black theologians cannot accept any conception of God, which stifles black self-determination by picturing God as a God of all people. Creator God is identified with the oppressed to the point that their experience becomes God's experience, or God is God of the racism (Cone 2010:67). The argument advanced by Cone (2010) leads to the point that Jesus is God and needs to be identified as Black because of black people's experience in Africa and the diaspora. It is essential to re-emphasise the Blackness of Jesus to locate Black people as God's elects because electing and elected Jesus is black and is taking the side of the poor and oppressed people in South Africa.

According to Cone (1997), black Christ is more than a theological issue. Cone (1997) states:

I realised that many white critics of black theology questions 'blackness' as a Christological title because it appears to be determined exclusively by black people's psychological and political needs to relate theology to the emergence of black power in the later 1960s. That is only partly true. The phrase 'Black Christ' refers to more subjective states and political expediency of Black people at a given point in history. (p. 122)

The placement of black people in the equation of God's doctrine under the following loci, predestination, creation and providence, needs to seek and find Jesus' identity and relationship with the black people within black theology of liberation. Cone locates Jesus within the African black people as black to deconstruct the New Testament's distortion on black Christ for political agenda (Cone 1997:123). Furthermore, he attempted to unmask the subjective interests of white theologians in the past; in that sense, current history needs to be re-evaluated through decoloniality. There are currently negative reactions from Westerners and white theologians to the black Christ. This negative reaction is almost exclusively to their whiteness and supersessionalism that they are replacing the ancient Israelites in South Africa; therefore, Christ must be white. Cone (1997) postulates:

White theologians' attitude towards black people in particular and oppressed generally is hardly different from that of oppressors in any society. It is particularly similar to the religious leaders' attitude toward Jesus in the first century Palestine when he freely associated with the poor and outcasts and declared that the kingdom of God is for those called and not for priests and theologians or any of the self-designated righteous people. (p. 123)
James Cone has laid the foundation for evaluating the theological loci amid the struggle for liberation for Black people at any given time in history. He places Jesus' experience, attitude and reaction to the poor, oppressed, dispossessed and wrong in the centre of his theology, besides Christology. Philosopher Cloete (2016) concur with Cone on reflection of the same attitude in the 2020's era:

The most damaging consequence of White epistemic ignorance is a pathological failure to face - and thus live meaningfully-in the present political reality. The political children of White supremacy will, therefore, seek to escape the 'truth' of the present by clinging either to a fabricated heroic past that 'never was', on the one hand, or an idealised future, on the other, that will 'never will be' in a bid to find metaphysical comfort in the present. From this perspective, metaphysical comfort is nothing more than a tragic manifestation of cognitive dissonance and distortion of present reality, which makes it extremely difficult to connect with the 'Other' human being in a meaningful way. (p. 26)

The black theology of Cone used in this article is based on his experience in the 1960's attitude of the oppressors and colonisers, which many in South Africa will dispute these claims based on the so-called free and democratic South Africa or in the liberated United States of America. There are reflections of such attitudes as Cone puts them, and Cloete confirms in the above quote. The following are the reflections of such attitudes.

Throughout history, the brutal killings of black people signify that Christ needs to be on the side of the elects (black people). The attitude of the oppressors of the 1960s is reflected in the murder of Matlhomola Mosweu, a black male teenager (16 years) at Coligny (SA) in April 2017, who died after his neck broke from being thrown out of the moving truck (Independent 2019). Similarly, George Floyd, a black man (46 years) in Minneapolis, Minnesota (USA) on 25 May 2020, died after being suffocated by a white police officer's knee on his neck. Furthermore, Mothoagae (2016:63) cites the brutal death of Moses Tatane and the Marikana massacre as the propositions that struggle for justice against apartheid in South Africa and the civil rights movement in the United States of America failed. These narratives and many more across the world are clear signs of the need for a robust black theology of liberation voice and re-evaluation of doctrines such as the doctrine predestination, which are used to justify oppression and racism in South Africa and elsewhere in the world. These stories triggered the mind to ask where Christ could be placed in this moment of the black suffering. Who is this Christ in this experience? James Cone assists black theologians of our times in understanding who this Christ is. He places Jesus as the black Christ for black people.

The nationality and ethnicity of Jesus played a significant role in the black theology of James Cone. Cone emphasised that Jesus was a Jew. The soteriological experience and attitude of Jesus provide the meaning of his Jewishness' particularity. Theology must confirm the Christological significance of Jesus' current blackness. Cone (1997) affirms: 
He is black because he was a Jew. The Black Christ's affirmation can be understood when the significance of his past Jewishness is related dialectically to the significance of his present blackness. On the one hand, the Jewishness of Jesus located him in the Exodus context, thereby connecting his appearance in Palestine with God's Liberation of oppressed Israelites from Egypt. (p. 123)

The black Jesus, whom James Cone defined above, is the very same Jesus that Karl Barth defines as the elected and electing God. The same Jesus is the one who identifies himself with the black people of South Africa in particular and Africans in Africa and diaspora in general. The blackness of Jesus is in the sense that he becomes one with oppressed blacks, taking their suffering as his suffering and revealing that he is found in the history of black people's struggling, the narrative of black pain and the rhythm of black bodies. He is the same Jesus (God) who stands with the poor, widows, orphans, destitute, oppressed and wronged who are suffering (Belhar Confession 1986; Cone 1997). If Jesus is the elected and electing, then one can make a deduction that black people are elected with Jesus, who is on the side of the poor, oppressed and dispossessed. The cross of Jesus symbolises that the one elected has replaced Israel's place as the suffering servant and thus reveals the Godly willingness to suffer so that humanity might be fully liberated. Whilst the resurrection is God's victory over oppression and injustice, disclosing that Godly freedom reveals in Israel's history is now available to all. The cross stands for divine suffering in Israel's place. The resurrection is divine freedom for all who labour and are heavily laden (Cone 1997:124).

With the election of Israelite slaves as God's people and becoming the oppressed one in Jesus Christ, humanity is made to understand that God is known where humanity experiences humiliation and suffering. It does not mean God feels sorry and pity on the suffering quite the opposite; God's election of Israel and incarnation in Christ expose that the liberation of the oppressed is part of the innermost nature of God. Liberation is not an afterthought but the essence of Godly activity (Cone 2010:67). The postulation based on James Cone's $(1997,2010)$ argument is that God in Christ came and continues to come to the poor, oppressed and dispossessed with the purpose to liberate them as he mentions in his ministerial mission statement that I have come to preach the good news to the poor. He emphasised that black people are God's elected in America; therefore, black people are elected in South Africa against the distorted reformed theology of the white people of South Africa that the prosperous oppressors and dispossessors are the elects of God. The God who elects black people is God who provides those people with land, minerals and food.

\section{Providence of God for the elects}

At the beginning of creation, God the creator provided space, light, land, water, atmosphere, plants and animals for God's elect to prepare for humanity to live on earth. Providence handled in the middle of predestination and creation.
Predestination and providence have the common origin in the absolute decree, a monistic bond joins them and they do not oppose each other (Thielicke 1969:574). Hence, I argue that predestination should correspond with providence. based on Jesus, black people are the elects, the elected and electing one, and the elected and electing is black as is already argued above. The second argument is that the elected and electing God provides for the elects. The abundance in Africa for Africans to have land and food security also shows that black people are the elects. In this article, the focus is on special Providence.

Calvin (2008:119) postulates that specific events are pieces of evidence of the special providence of God. In the wilderness, God provides birds to the hungry Israelite slaves who are liberated from Egypt. Birds, food and protection are from God in the form of special Providence, not a fate (Calvin 2008:119). In the black African context, God's Providence is seen and experienced right from the primary source of photosynthesis, which is when food and oxygen are generated for human beings. The African people appreciate the sunlight from God as special Providence. Mbiti (1969:41), for instance, gave names of God that define God as provider and sustainer of the lives of people:

- Ovimbundu: It means 'He who supplies the needs of His creatures. This is a fundamental belief about God, and the examples come from all over Africa. God provides life, fertility, rain, health and other necessities needed for sustaining the creation'.

- The Shining One: 'Sunshine is one of the expressions of God's Providence. Africans believe that the sun symbolises God's benevolence, an expression of His Providence'.

- The rain-giver: 'Rain is acknowledged as the token of God's Providence. Rain is always a blessing, and its supply is everywhere'.

- Provider of land and health: 'Cattle and fields, sufficiency in food, children and other goods like golds, diamonds, platinum, minerals etc. are provided by God to humans'.

- The Protector of the poor: 'God is the keeper of life of the poor' (Mbiti 1969:41).

These names or praise names for God in the African theology signify God's importance within African societies. As outlined by John Mbiti, Providence indicates that God, who has elected Jesus to elect his people, is God of black and African people. The sun's provision as the Shining One is the One who has elected the black people; he has given them the black skin. The abundance of land for cattle and plants for humanity is the sign of election as Weber indicates that God's blessings show election; abundance and wealth are the signs of election. The British settlers confirm that South Africa is fruitful and have in abundance the required resources for life. They affirm that the country has the most delicate soil and climate in the world. It commands the commerce of the globe. It produces in unparalleled abundance all the necessaries and all luxuries of life. It is the natural gateway to India and can supersede entire Europe in supplying with 
accustomed articles of importation (Magubane 2007:189). Jesus, the elected and electing one who is black, together with God the creator, have elected blacks and the indigenous nations in Africa pre-temporal and provided them with the abundance that will sustain them for life in abundance. In this sense, predestination, creation and Providence cannot be separated in theology.

\section{Conclusion}

The doctrine of predestination was and is distorted in South Africa to ease the consciousness of the oppressors to oppress, dispossess and exploit the black people. This article's thesis is to deconstruct the constructed ideology that black people have fallen out of the grace of God and are the rejects whilst white people are the elects. The central problem is that who are the elect? The poor or the rich? The black people or the white people? Throughout the history of theology, this doctrine is hanging without locating the elects to people of God. In this article, I have attempted to illustrate that Jesus, the elected and electing one, is black and is in solidarity with the suffering of black people. The elects as fallen human beings sometimes fall out of God's grace, like the Israelites who were the biblical elects.

The following was found based on the problem statement:

- It was found that the doctrine of predestination was the foundation for the white people's nationalism and a justification for oppression, dispossession and exploitation of the black people:

- It was found black people were located outside the grace of God as the elect in South Africa.

- The reading of Karl Barth's doctrine of predestination has shown that Jesus is the elected and the electing God, whilst James Cone locates Jesus who is the elected and electing God as a black person.

- The blackness of Jesus warrants the black people to be the elects because the electing and elected God is like them and in solidarity with them.

- It was found that this evaluation and location of black people as the elect is necessary because of their white counterparts' experiences and attitudes, the death of Matlhomola Mosweu and George Floyd.

- The abundance in resources and land in South Africa in particular and Africa in general indicates that the God who elects is the One who provides. The doctrine of predestination and Providence cannot be separated.

- Finally, it was found that black people are the elects in terms of black Christology, Providence and protection of the keeper of the poor.

In most cases, they fell out of the Grace of God and were sent to exile to repent and restructure their identity and return to their rightful position. This article reawakens the black people to their rightful place as the elects of God, which needs to restructure their lives as those provided with resources to feed themselves and export the surplus to the other nations.

\section{Acknowledgements Competing interests}

The author declares that he has no financial or personal relationships that may have inappropriately influenced him in writing this article.

\section{Author's contributions}

L.J.M. is the sole author of this article.

\section{Ethical considerations}

This article followed all ethical standards for research without direct contact with human or animal subjects.

\section{Funding information}

This research received no specific grant from any funding agency in the public, commercial, or not-for-profit sectors.

\section{Data availability}

Data sharing is not applicable to this article as no new data were created or analysed in this study.

\section{Disclaimer}

The views and opinions expressed in this article are those of the author and do not necessarily reflect the official policy or position of any affiliated agency of the author.

\section{References}

Barth, K., 1957, Church Dogmatics: The doctrine of God, T\&T. Clark, Edinburgh Belhar Confession, 1986, Belhar Confession, Christian Literature Fund Publishers, Wellington. Bonhoeffer, 2012, 'State and church', in W.T. Cavanaugh, J.W. Bailey \& C. Hovey (eds.), An Eerdmans reader in contemporary political theology, William B. Eerdmans Publishing Company, Grand Rapids, MI.

Calvin, J., 2009, Institutes of the Christian Religion, Hendrickson Publishers, Massachusetts.

Cloete, M., 2016, 'Allan Boesak: Innocence and the struggle for humanity', Acto Theologica Supplementary 24, 17-42.

Cone, J.H., 1997, God of the oppressed, Orbis Books, New York, NY.

Cone, J.H., 2010, Black theology of liberation, Orbis Books, New York, NY.

Dolamo, R.T.H., 2016, 'Does Black Theology have a role to play in the Democratic South Africa?', Acta Theologica Supplementary 24, 43-61.

Hunsinger, 2012, 'Introduction', in W.T. Cavanaugh, J.W. Bailey \& C. Hovey (eds.), An Eerdmans reader in contemporary political theology, William B. Eerdmans Publishing Company, Grand Rapids, MI.

Independent, 2019, Pieter Doorewaard and Phillip Schutte, found guilty of killing a teenager, viewed 07 March 2019, from https://www.independent.ie/world-news/africa/white

Magubane, B.M., 2007, Race and the construction of the construction of the dispensable other, Unisa Press, Pretoria.

Mbiti, J.S., 1969, African religions and philosophy, Heinemann, London.

Metz, J.B., 2012, 'Theology in the new paradigm: Political theology', in W.T. Cavanaugh, J.W. Bailey \& C. Hovey (eds.), An Eerdmans reader in contemporary political theology, William B. Eerdmans Publishing Company, Grand Rapids, MI.

Mothoagae, I., 2016, 'Reclaiming our Black bodies: Reflections on a portrait of Sarah (Saartjie) Baartman and destruction of black bodies by the state', Acta Theologica Supplementary 24, 62-83.

Resane, K.T., 2017, Communion ecclesiology: In a racially polarised South Africa, Sun Press, Bloemfontein.

Thielicke, H., 1969, Theological ethics: Politics, William B. Eerdmans Publishing Company, Grand Rapids, MI.

Vasilopoulos, C., 2012, The triumph of hate: The political theology of the Hilter Movement, University Press of America, Lanham, MD. 